
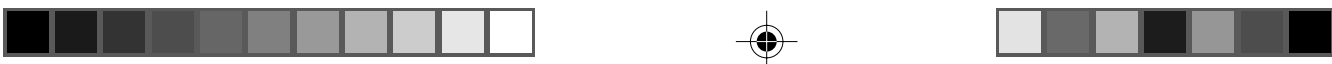

\title{
SPROGMØDET SET MED KULTURTEORETISKE BRILLER
}

\author{
KAREN RISAGER
}

Hensigten med denne artikel er at vise hvordan sprogvidenskab og kulturvidenskab kan komme i dialog med hinanden og udvikle det felt, der ligger i interfacet mellem dem, studiet af sprog som kultur. Her er hovedvægten ikke på sprogets formside, dets grammatik og fonologi, men på dets indholdsside, dets betydningsbærende og betydningsskabende side. Jeg ser således på sproget med kulturteoretiske briller og analyserer sproget som socialt struktureret betydningspraksis med overordnet reference til Ulf Hannerz' arbejde (1992) med kulturelle strømme og kulturel kompleksitet og Michael Agars arbejde (1994) med sprogkultur-begrebet.

Sprogstudierne i almindelighed, og også studierne af sprog som kultur, må nødvendigvis tage udgangspunkt i den sproglige kompleksitet i samfundene og $\mathrm{i}$ verden. Transnational migration og andre former for geografisk og social mobilitet medfører, at mange forskellige sprog spredes rundt omkring i verden og 'mødes' i sprogligt stadig mere komplekse samfund. Derfor er det oplagt at videreudvikle kulturstudierne ved blandt andet at beskæftige sig med sprogm $\phi$ det og dets mange kulturelle og sociale dimensioner. Dette forskningsfelt er ganske nyt, ikke mindst hvad angår den kulturelle dimension (Risager 2003, 2006).

\section{Et sprogmøde en miniature}

Der er mange forskellige former for sprogmøde (eller sprogkontakt, som det også hedder), og jeg vil tage udgangspunkt i en type der er bevidst konstrueret, og som hører til på mikroplanet. Det er et eksempel, som jeg stødte på en gang i begyndelsen af 1990'erne på Bornholm: Buy some petit souvenir aus Dänemark! Denne sætning var skrevet på et skilt, der vistnok var sat op på et postkontor, og det var højst sandsynligt konstrueret for at virke i den danske turistmæssige sammenhæng med mange gæster fra forskellige dele af Europa og resten af verden (Risager 1993). 

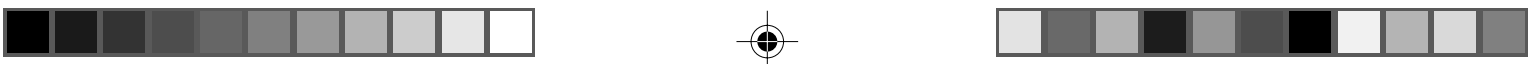

For den der har et minimalt kendskab til henholdsvis engelsk, fransk og tysk, vil det umiddelbart stå klart, at der her er tale om en sætning indeholdende ord fra engelsk, fransk og tysk. Det er samtidig en sætning der fungerer som en fint sammenhængende enhed. Grafisk fungerer den som enhed fordi der er tale om samme skriftsystem, det latinske alfabet. Grammatisk fungerer den som en enhed, fordi der er en (for målgruppen) genkendelig grammatisk struktur, som er typisk for mange af de europæiske sprog, verballed + objekt + bestemmerled (subjektet er ikke udtrykt, hvilket viser, at der potentielt er tale om en opfordring). Semantisk fungerer den som en enhed, fordi den giver læseren anledning til at forestille sig en plausibel indholdsmæssig sammenhæng og til at foretage en reference til den samfundsmæssige virkelighed. Pragmatisk fungerer den som en enhed, idet der er tale om en bestemt genkendelig sproghandling, en opfordring til køb.

De to engelske ord kan nok forstås af de fleste der har lært sig noget engelsk som fremmedsprog, og det har de fleste mennesker i Europa, i hvert fald dem der kan rejse til udlandet og købe souvenirs. De to franske ord, især 'souvenir', er meget almindelige låneord i europæiske sprog, inklusive dansk, engelsk og tysk. Af de to tyske ord kan 'Dänemark' genkendes af de fleste, da der er tale om et egennavn (et stednavn), og egennavne undergår som regel kun små ændringer fra sprog til sprog (Danmark, Denmark, Danemark, Dänmark).

Den grammatiske struktur i sætningen kan angives som: 'buy' (verballed), 'some petit souvenir' (objekt) og 'aus Dänemark' (præpositionsled der 'lægger sig til' eller bestemmer objektet). Men det er interessant, at der er brugt 'some' og ikke 'un'. Overgangen fra det engelske til det franske går midt ned igennem objektet og ligger på grænsen mellem bestemmelsen 'some' og nominalleddet 'petit souvenir'. Der kunne være flere grunde til dette valg. Dels kan man forestille sig, at designeren af sætningen mener, at 'some' vil være mere genkendelig end 'un'. Dels kan man forestille sig, at designeren også har haft en poetisk intention og har bygget sætningen op omkring en simpel matematisk struktur indeholdende to ord fra hvert af de tre sprog. Det ville også forklare, hvorfor 'petit' er med, hvilket jo ikke er nødvendigt for meningen (selv om det heller ikke er en irrelevant tilføjelse idet 'lille' kan implicere billig og ønskværdig).

Man kan betegne sætningen som et lille brugsdigt, og det virker på baggrund af en tværsproglig genkendelighed i både struktur og ordforråd. Virkningen forudsætter på den anden side, at målgruppen har forholdsvis vide sprogkompetencer, der omfatter kendskab til (i det mindste rudimenter af) engelsk, fransk og tysk.

Den slags bevidst konstruerede sprogmøder træffer man mange af i Danmark i disse år, i sangtekster, reklamer og filmdialoger, fx i serien „The Julekalender“", hvor der leges med blandinger af dansk (jysk) og engelsk. Ligesom med ovenstående eksempel kan det ses som prøver på sproglig kreativitet i det skriftlige 

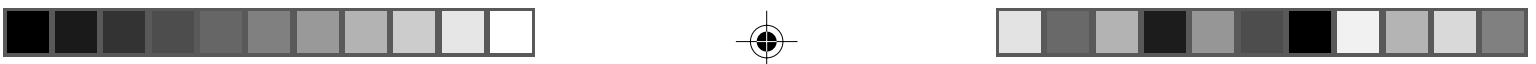

medium eller i en mere eller mindre stiliseret samtale. Samtidig repræsenterer de brud på den hegemoniske sproglige norm, der går ud fra, at det rene ublandede sprog til enhver tid er normen både i skrift og i tale.

Buy some petit souvenir aus Dänemark! er altså et sprogmøde. Dermed mener jeg ganske vist ikke, at tre forskellige sprog mødes her i abstrakt forstand. Der er tale om skriftligt formidlet kommunikation mellem mennesker. Konkret er der tale om, at en eller flere (mindst) tresprogede voksne personer har designet en lille tresproget tekst, som henvender sig til en tænkt målgruppe af voksne personer, der er (mindst) tresprogede med de samme sprog. Med en 'tresproget' person mener jeg ikke en person, der har høj kompetence i alle tre sprog. Flersprogede kompetencer er sædvanligvis sammensat sådan, at man kan nogle sprog bedre end andre og har forskelligt forhold til dem. Kompetencerne kan variere meget i forhold til lytteforståelse, samtalefærdighed, læse- og skrivefærdighed og i forhold til den specifikke kommunikationssituation og emnets karakter. Den lille tekst forudsætter som sagt ikke høje sprogkompetencer hos læserne, men den forudsætter dog, at læserne kan genkende den som tresproget med netop engelsk, fransk og tysk. Man kan sige, at teksten er tresproget i to omgange: først for designeren/designerne, som har konstrueret den, og dernæst for læserne, men kun for de læsere, der kan se, at der er tale om tre forskellige sprog.

\section{Sprogmøder på mikroplanet: samtaler og tekstoversættelse}

Siden den tidlige udvikling af det menneskelige sprog og den omfattende differentiering i mange forskellige talesprog har der utvivlsomt været mobilitet og kommunikation på tværs af sprogsamfundene. Der har altid fundet sprogmøder sted, fx samtaler hvor mennesker, der kunne mere end ét sprog, kommunikerede med hinanden eller formidlede mellem andre grupper af mennesker, der ikke havde noget fælles sprog.

I moderne komplekse og flersprogede samfund er der mange sprogmøder i hverdagens mundtlige kommunikation, ikke mindst i de fleretniske storbyer. Det er nok ikke muligt at give et overblik over omfanget og arten af sprogmøder i en by eller et bykvarter, men en række sociolingvistiske studier i de sidste 20-25 år (fx Le Page \& Tabouret-Keller 1985; Rampton 1995; Jørgensen 2003; Pavlenko \& Blackledge 2004; Quist 2005; Harris 2006) peger på flere former for sprogmøder, fx i den mundtlige kommunikation blandt unge, der har tilknytning til forskellige sproggrupper (men også i den kvasi-mundtlige kommunikation i sms, chat og e-mails).

En form for sprogmøde er samtale med kodeskift, dvs. skift mellem (mindst) to forskellige sprog (Auer 1998; Jørgensen 2003). I nogle tilfælde er der tale om 

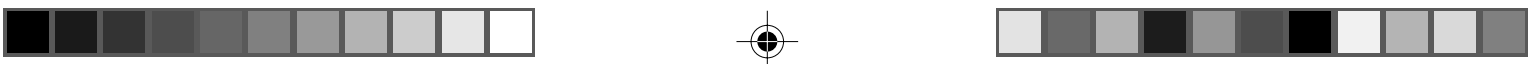

intersententielt kodeskift, dvs. skift ved en sætningsgrænse, fx når man mellem danskere skifter fra at tale dansk til at tale engelsk, når man vil inddrage en der ikke kan dansk, men engelsk. Her er der altså tale om at man skifter sprog af forståelseshensyn, og længere passager af samtalen foregår på ét sprog. I andre tilfælde kan der være tale om intrasententielt kodeskift, dvs. skift både inde i og mellem sætningerne, og det er almindeligt når to mennesker, der begge både kan tale $\mathrm{og}$ forstå hinandens sprog, skifter frem og tilbage mellem sprogene, ikke for at sikre forståelsen, men af andre grunde, fx for at markere kulturel identitet eller for at signalere, hvem der har magten (til at vælge sprog). Eksemplet Buy some petit souvenir aus Dänemark kan for så vidt ses som en stilisering af kodeskift, hvor der tages udgangspunkt i engelsk, og hvor der så indlemmes noget fransk og noget tysk.

En anden form for sprogmøde er det man kalder crossing (Rampton 1995), hvor der i samtaler i ét sprog indlemmes ord og vendinger fra et eller flere andre sprog, som kendes i miljøet, men som man ikke nødvendigvis selv behersker. Det kan fx være brug af arabiske og tyrkiske ord i en ellers dansk samtale (multietnolekt eller multietnisk stil, se Quist 2005).

En tredje form for sprogmøde er det man kalder polyglot dialog, hvor den ene samtalepartner taler ét sprog, og den anden taler et andet, men begge forstår hinandens sprog. Dette er fx almindeligt i samtaler mellem danskere, svenskere og nordmænd, der taler hvert sit sprog og forstår hinanden (mere eller mindre). Noget tilsvarende kan man se i samtaler mellem folk der taler dansk som modersmål, og folk der taler dansk som andetsprog. De taler hver sin etnolekt af dansk, men forstår hinanden (mere eller mindre). Denne synsmåde kan i og for sig udstrækkes til al samtale, idet alle jo taler mere eller mindre forskelligt. I denne forstand er al samtale polyglot dialog, jf. Bakhtins begreb heteroglossi (Bakhtin 1981).

En fjerde mere konventionaliseret form for sprogmøde er den tolkede samtale. Her er der (normalt) en vekslen mellem to sprog, formidlet og til dels styret af en tosproget tolk. Sprogmødet er først og fremmest betinget af forståelseshensyn.

Sidst, men ikke mindst, skal nævnes en femte form, nemlig oversattelsen. Her er der i selve oversættelsesprocessen tale om, at en tosproget person overfører en (skriftlig) kildetekst i ét sprog til en (som oftest også skriftlig) måltekst på et andet sprog.

\section{Sprogmøder på makroplanet -sproglig mangfoldighed}

De beskrevne eksempler på sprogmøder foregår på mikroplanet, men de er illustrationer af bredere samfundsmæssige processer, hvor mennesker bevæger sig rundt $\mathrm{i}$ verden og bringer deres sproglige kompetencer og erfaringer med sig. 

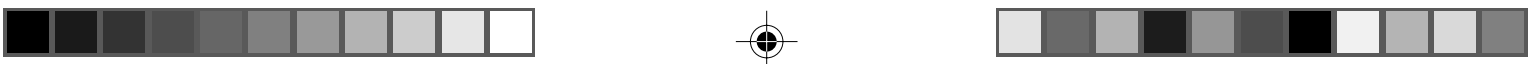

Som følge af denne lokale og transnationale mobilitet dannes der hele tiden nye lokale konfigurationer af sproglig mangfoldighed. Mangfoldigheden er struktureret socialt, og man kan tale om sprogmøder på mange planer og i mange sammenhænge, i familier, kvarterer, institutioner, organisationer, medier osv. op til det globale makroplan.

I det danske samfund kan man fx tale om to overordnede sprogmødesituationer, på den ene side dansk vs. engelsk, på den anden side dansk vs. de såkaldte indvandrersprog. Det er disse to overordnede sprogmøder, der er mest debat om. Men dette skal ses på baggrund af en stor og mere eller mindre usynlig sproglig mangfoldighed, der spænder over ca. 120 sprog med stærkt varierende antal brugere (Risager 2005, 2006).

\section{Ideen om identitet mellem sprog og kultur}

I sprogvidenskaben har der siden starten af 1800-tallet været en strømning, der var overbevist om, at sprog, folk og nation (og i en vis forstand kultur) var tæt forbundne, en idé som den tysktalende J.G. Herder var den første til at formulere i 1760'erne, og som den tyske nationalromantik i perioden ca. 1795-1830 dyrkede i særlig grad. Det blev efterhånden til overbevisninger, der kredsede omkring sådanne udsagn som at „,sprog og kultur er uadskillelige“, ,,sprog og kultur er identiske“, ,,sprog er kultur og kultur er sprog“. Sådanne forestillinger blev ganske vist udelukket af det meste af den strukturalistiske og autonome sprogvidenskab fra 1920'erne til 1950'erne, men blev genoptaget af en række nyere sprogvidenskabelige discipliner i 1960'erne og 1970'erne, ikke mindst af dem der beskæftiger sig med bestemte sprog og med sproglig forskellighed, fremmedsprogspædagogik, litterær og ikke-litterær oversættelsesteori og tværkulturel pragmatik (Risager 2003). Overbevisningen toppede i 1980 'erne og 1990'erne, hvor nogen inden for fremmedsprogspædagogik fx begyndte at beskrive sprogundervisningens genstand som 'language-and-culture' (også som adjektiv, 'language-and-cultural') (Byram, Morgan et al. 1994; Roberts et al. 2001).

Denne stærke fremhævning af en entydig og nødvendig sammenhæng mellem sprog og kultur indebærer en risiko for at man dyrker en kulturforståelse, der er fuldstændig sprogafledt. Den forudsætter, at der til ethvert sprog hører en kultur, og alt hvad der ikke har noget med sproget at gøre, lades ude af syne. En sådan kulturforståelse er klart utilfredsstillende inden for en bredere kulturstudiesammenhæng, hvor sproget behandles som blot én af de mange tænkelige parametre. Hvis man ser på eksemplet Buy some petit souvenir aus Dänemark, ville det også være alt for generaliserende og faktisk misvisende at sige, at her mødes 'engelsk kultur', 'fransk kultur' og 'tysk kultur'. 


\section{Ideen om sproget som en kulturneutral kode}

På den anden side vil jeg, og mange med mig, fastholde, at sproget ikke er kulturneutralt. Sproget er bærer af (og medkonstituerende af) betydning, mening og diskurs og er dermed i helt overordnet forstand kulturligt. Men det er ikke alle inden for sprogvidenskaben (lingvistikken), der har dette standpunkt. De fleste lingvister opfatter sig ikke som kulturanalytikere, men interesserer sig for sproget som en særlig kompetence eller et funktionelt redskab til sproglig handlen. Det gælder især dem, der tager udgangspunkt i engelsk, hvad enten man betragter engelsk som repræsentativt for det menneskelige sprog generelt og derfor ikke har øje for det engelske sprogs kulturelle specificitet, eller man fokuserer på det engelske sprog i dets egenskab af internationalt kommunikationssprog eller lingua franca. I det sidste tilfælde er den fremherskende idé, at det engelske sprog i denne rolle er frigjort fra sine kulturelle, nationale bindinger og kan bruges overalt og i alle situationer. Kritikere af denne idé fremhæver, at det engelske sprog ikke må forstås som en kulturneutral kode, men at det under alle omstændigheder er produkt af en specifik historie (blandt andet Pennycook 1998).

Hvis man ser på eksemplet Buy some petit souvenir aus Dänemark, ville man miste nogle dimensioner, hvis man ikke undersøgte, hvilke betydninger der lægges op til, eller som kan dannes i kraft af at der er tale om elementer fra tre forskellige sprog. Eksemplet repræsenterer efter min mening en kulturel kompleksitet en miniature.

\section{Sprogkulturbegrebet}

For at kunne belyse sprogets kulturelle dimension må man udvikle et begreb, der ligger i interfacet mellem sproget og resten af kulturen. Jeg har andetsteds argumenteret for, at et sådant begreb kan være sprogkulturbegrebet (Risager 2003, 2006). Dette begreb har kun været sporadisk brugt tidligere. Den der har gjort mest ud af det, er den amerikanske antropolog Michael Agar, der skriver om begrebet languaculture (Agar 1994). Han har overtaget begrebet fra Paul Friedrich, der kalder det linguaculture (Friedrich 1989). Agar skriver blandt andet følgende om sit syn på sprog og kultur:

\footnotetext{
Sproget, i alle dets varieteter og på alle de måder, det fremtræder i hverdagslivet, opbygger en verden af betydninger. Når du løber ind i forskellige betydninger, når du bliver opmærksom på dine egne betydninger og arbejder på at bygge en bro til andres, så er det 'kultur' du er i gang med. Sproget fylder rummet mellem os med lyd; kulturen smeder den menneskelige forbindelse gennem den. Kulturen er i sproget, og sproget er fyldt med kultur (Agar 1996: 28; min oversættelse, KR).
} 

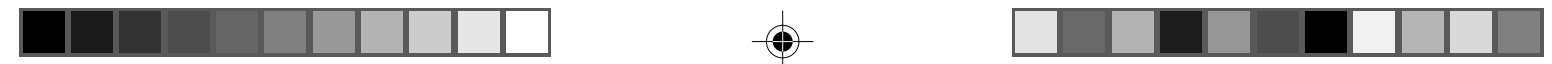

Han siger endvidere om languaculture, at det er ,det nødvendige bånd mellem sprog og kultur“ (op.cit. 60; min oversættelse, KR). Agar beskæftiger sig med samtaler, hvor deltagerne taler ud fra forskellige kulturelle forudsætninger, uanset at de måske taler samme sprog, fx engelsk. Han er først og fremmest interesseret $i$ at analysere kulturelle misforståelser på det interpersonelle mikroplan. I den forbindelse understreger han stærkt forbindelsen mellem sprog og kultur i den enkelte samtalesituation og inviterer også til at søge efter mere generelle mønstre eller frames for kommunikation og interaktion mellem mennesker med forskellige sproglige og kulturelle forudsætninger. Om frames siger han blandt andet: „Frames tager sprog og kultur og gør dem uadskillelige. Ordet 'og' forsvinder, og så har vi languaculture“" (op.cit. 132; min oversættelse, KR).

Jeg deler Agars integrative sprogsyn og mener ligesom han, at det er nødvendigt og meget givende at analysere sproglig praksis som en integreret del af den $\emptyset$ vrige kulturelle og sociale praksis og de samfundsmæssige omstændigheder i $\emptyset$ vrigt. Men jeg ser det problem med Agars tilgang, at den stærke fremhævning af uadskilleligheden mellem sprog og kultur underspiller forskellighed. Når jeg fx drager til Kina sammen med en lille gruppe dansktalende, så bruger vi dansk sammen, men i en kulturel kontekst der på visse punkter er forskellig fra den danske. Det kan betyde noget for vores dansksproglige praksis, fx referencer til lokale steder, personer og begivenheder. Og det vil i særdeleshed betyde noget for den status, det danske sprog har. Nogle kinesere ved ikke, at der findes et særligt dansk sprog (,,what language do you speak in Denmark?“), nogle kender det som et lille europæisk sprog, som tales af meget få. Derfor er der brug for et sprogkulturbegreb, der knyttes stærkere til det enkelte individs sprog, og som tillader det synspunkt, at når individet flytter sig til en anden kulturel kontekst end modersmålskonteksten, så dannes der en ny facet af kulturel kompleksitet, som man må forholde sig til empirisk. Det er for forenklende at hævde, at sprog og kultur altid er uadskillelige.

Der er også et andet punkt i Agars tilgang, som jeg finder utilstrækkeligt. Hans begreb om languaculture retter sig specielt mod sprogets semantik og pragmatik, altså de betydninger som vi lægger i ord, vendinger og diskurser (hvilke betydninger lægger vi fx i udtryk som 'familie', 'om lidt', 'frihed', 'den syvende himmel', 'hunden er menneskets bedste ven'?). Men når man ser på sprogvidenskaben som helhed, så er der to andre felter, der også beskæftiger sig med sproglig betydning, nemlig poetikken og sociolingvistikken. Der er derfor brug for et begreb, der kan dække hele spektret af sproglig betydning.

Hvor semantikken og pragmatikken fokuserer på sprogets indholdsside, så fokuserer poetikken, specielt i traditionen fra Jabobson (1960), på samspillet mellem indholdssiden og udtrykssiden. Når vi fx i Politikens ATS læser om 

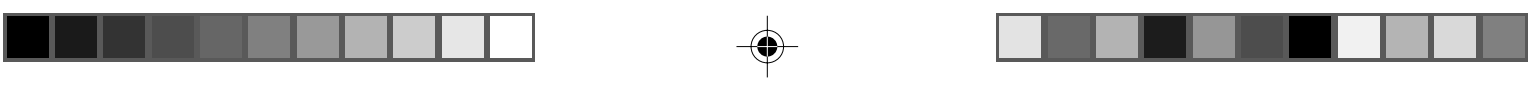

'Dolketinget', 'Mogens Jamre', 'Tortour de France' og 'Hvæsernes redaktør', så forstår vi humoren, fordi der er et delvist sammenfald på udtrykssiden mellem fx 'Dolketinget' og 'Folketinget'. De rimer.

I sociolingvistikken er der nogle, der beskæftiger sig med sproglig betydning. Dette kaldes undertiden social meaning (Hymes 1974), og i den nyere forskning forbindes det typisk med identitetsbegrebet. Det der her fokuseres på, er den betydning eller identitetshandling, der ligger i at sprogbrugerne vælger ét sprog frem for et andet, eller én sprogvarietet frem for en anden. Hvad betyder det $\mathrm{i}$ situationen, at man vælger engelsk frem for dansk? Hvad betyder det, at man taler rigsdansk frem for sjællandsk? Her ligger fokus på udtrykssiden, for man interesserer sig ikke for indholdet af det der bliver sagt, kun for hvilken kode der er valgt, og hvad dette betyder for den sproglige identitet.

Sammenfattende kan man sige, at sprogkulturbegrebet skal tillade en sammentænkning af disse tre (allerede veludviklede) forskningsfelter. Samtidig mener jeg, at man må give dem alle tre en særlig drejning hen imod studiet af den personlige sprogkultur, som den udvikler sig gennem hele livet. På denne måde er der mulighed for at teoretisere, at mennesket har 'fødder' i sprog og kultur, ikke 'rødder'. I de følgende afsnit vil jeg uddybe de forskellige dimensioner af sprogkulturen.

\section{Den semantisk-pragmatiske dimension af sprogkulturen}

Den semantisk-pragmatiske dimension fokuserer som sagt på sprogets indholdsside: Hvilke semantisk-pragmatiske ressourcer og begrænsninger har de forskellige sprog? Hvis vi ser på vores lille eksempel med Buy some petit souvenir aus Dänemark, så har vi at gøre med tre sprogkulturer, der er delvist forskellige. Det engelske 'buy' dækker fx over både ental og flertal, hvor man på både fransk og tysk måtte overveje, om man skulle vælge flertalsformen (høflighedsformen) eller entalsformen ('achetez' eller 'achète', 'kaufen Sie' eller 'kauf'). 'Some' indgår $i$ et semantisk felt i modsætning til 'any'. Denne specifikke modsætning findes ikke i fransk eller tysk. Det franske 'souvenir' har i det franske sprogsamfund en betydning, der på dansk kan gengives med 'erindring', dvs. at det har et meget mere alment betydningsområde end det har som låneord i dansk og engelsk. 'Petit' er strukturelt særegent, idet det indgår i et lille antal foranstillede adjektiver med forholdsvis almen betydning; ellers er adjektiver normalt efterstillede ( $\mathrm{fx}$ 'un souvenir désagréable'). På tysk (og engelsk og dansk) bruges landenavnet 'Dänemark' uden artikel, men på fransk må man bruge 'du' (afledt af 'de' + 'le'), idet 'Danemark' er hankøn og derfor skal optræde med den bestemte artikel 'le'. 'Dänemark' optræder i sin tyske form med de kulturelle konnotationer dette kan give anledning til hos forskellige grupper eller individer. 

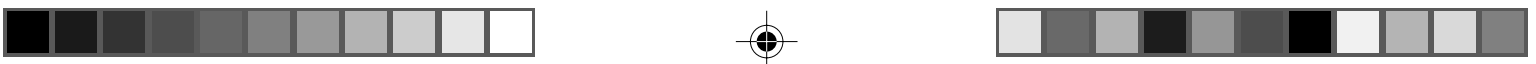

Der er altså for hvert af de tre sprog foretaget nogle delvist forskellige valg $\mathrm{i}$ sprogenes semantik og pragmatik, sådan som de er formet af den grammatiske struktur og betydningsmæssige relationer i ordforrådet. Alle valgene er dog ikke lige interessante i en kulturanalyse af eksemplet. Jeg vil mene, at det mest interessante er de potentielle konnotationer til 'souvenir' og 'Dänemark', og det kommer jeg tilbage til.

\section{Den poetiske dimension af sprogkulturen}

Den poetiske dimension fokuserer på sprogets udtryksside i dens strukturelle relation til indholdssiden. Hvilke udtryksmæssige ressourcer og begrænsninger har de forskellige sprog, og hvilke betingelser giver det for indholdet? Hvilke muligheder for rytme og rim, hvilke relationer mellem lyd og skrift osv.? I forhold til vores eksempel, Buy some petit souvenir aus Dänemark, er der tale om en sammenstilling af tre sprogs udtrykssider, og det skaber klart nogle spændinger på udtaleplanet. Efter at jeg havde set sætningen, havde jeg i længere tid svært ved at udtale den uden at snuble. De tre sprogs tryk- og rytmestruktur er temmelig forskellige; især adskiller den franske sig fra den engelske og tyske. Man kan prøve at efterligne en nogenlunde autentisk modersmålsudtale af hvert sprog (hvilket i sig selv er et problematisk spørgsmål, for hvilken udtalenorm skal man vælge, og hvilke grupper skal man vælge som repræsentanter for den?), men det giver nogle svære brud i talestrømmen. Jeg er selv landet på en modificeret udtale, som trækker hen i retning af dansk accent for hele sætningen, og dette betyder, at jeg laver fire trykgrupper med tryk på første stavelse i hver gruppe: Buy some - petit souve - nir aus - Dänemark. Det repræsenterer altså en udtalemæssig opdeling, der går på tværs af opdelingen i tre sprog. Samtidig bruger jeg så en udtale af souvenir (souvenir), der afviger fra det sædvanlige danske (souvenir). Et udtalekompromis man vel kan kalde hybridt.

Et andet aspekt af den poetiske dimension var jeg inde på i et tidligere afsnit; det at der er tale om to ord fra hvert sprog, er det mon udtryk for en poetisk hensigt på ordplanet, en regelmæssighed der måske tydeligst kan komme til udtryk i det grafiske billede?

\section{Den identitetsmæssige dimension af sprogkulturen}

Identitetsdimensionen fokuserer som sagt på udtrykssiden, nærmere betegnet på valget af sprog eller sprogvarietet. Hvordan udtrykker man sin sproglige identitet gennem valget af og brugen af sproget og derigennem måske (men ikke 

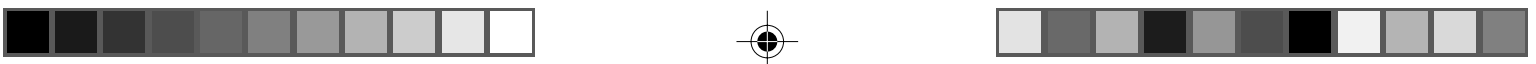

nødvendigvis) sin etniske, nationale, sociale identitet? Hvilke forestillinger skaber en tekst på tysk i modsætning til en på fransk, og for hvem?

Buy some petit souvenir aus Dänemark er interessant i identitetsdimensionen, fordi den sidestiller tre sproglige identiteter. Hvordan forstår læserne hentydningen til de tre sprog? Der er i hvert fald tale om tre skolesprog i den forstand, at de er almindelige fremmedsprog i uddannelsessystemerne i Europa. For turister i Danmark kunne man også have forestillet sig en sætning sammensat af ord fra svensk, tysk og polsk, men den ville nok ikke blive forstået af så mange. Derfor er valget af engelsk, fransk og tysk i vores eksempel en reference til ikke blot det internationale (turist)miljø i (først og fremmest) Nordvesteuropa, men også til uddannelsessystemernes fremmedsprogstilbud.

Sætningen ikke blot sidestiller de tre sprog, men ligestiller dem også, for så vidt at der (rent matematisk) er to ord til hver. På den anden side betyder rækkefølgen også noget, og sætningen starter jo i det engelske. Engelsk er her det ledende sprog, også kaldet 'matrixsproget', det sprog der så at sige lægger strukturen for resten af sætningen. Det er nok ikke tilfældigt, at det netop er engelsk, der er valgt, og her kan der gives både en identitetsmæssig og en semantiskpragmatisk forklaring. For det første bliver engelsk ofte, ikke mindst i Danmark, behandlet som det generaliserede fremmedsprog (fremmedsprog = engelsk); for det andet slipper man i engelsk for at skulle vælge mellem forskellige verbalformer, som man skal i tysk med 'kaufen Sie' over for 'kauf' (jf. ovenfor).

\section{Den personlige sprogkultur}

Det enkelte menneske udvikler sine sproglige kompetencer og ressourcer gennem hele livsforløbet i samspil med andre mennesker i sit specifikke miljø. Han/hun udvikler sin særlige måde at tale og forstå på, sin idiolekt. Idiolektens kulturelle dimension, dens sprogkultur, er den pågældendes personlige sprogkultur, som på den ene side i et vidt omfang deles af andre, der taler samme sprog, og på den anden side er unik for netop denne person. Den er unik, fordi den rummer de livshistorisk bestemte konnotationer, netop han/hun har til alle forhold i livet. Hvad forstår jeg ved 'souvenir'? Hvad forbinder jeg med 'Danmark' eller med 'Dänemark'? Hvad er mine erfaringer med at være turist? Et karakteristisk træk ved sprogkulturen i alle dens dimensioner er således spillet mellem relativ konstans og relativ variabilitet, mellem de aspekter af sprogkulturen, som er konstante i kraft af sprogets struktur og kollektive karakter, og de aspekter der er variable og kendetegnet af social, kulturel og individuel variabilitet. Grænsen mellem konstans og variabilitet ligger ikke fast; den er hele tiden til forhandling i den sproglige praksis. For eksempel er grænsen mellem et ords denotation (den konstante 

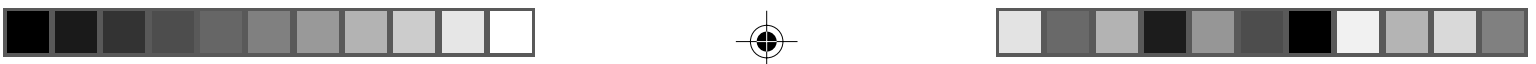

betydningskerne, hvis en sådan kan defineres) og konnotationer (de forskellige subjektive betydninger) i nogle tilfælde meget flydende, især ved de såkaldte 'flydende betegnere' (fx sådan ord som 'kultur' eller 'Danmark', der kan gives en stor mangfoldighed af betydninger).

I den nationalromantiske idé om uadskillelighed mellem sprog og kultur er det underforstået, at sproget tales som modersmål. Det er kun for den, der har lært sproget i barndommen, at det overhovedet giver mening at postulere en tæt sammenhæng mellem modersmålet og modersmålskulturen (die muttersprachliche Kultur, som det hedder på tysk). Men det er vigtigt at gøre sig klart, at forskellige sprog kan spille forskellige roller i menneskers liv. De kan være modersmål (førstesprog), andetsprog eller fremmedsprog (se Risager 2006 for en diskussion af disse begreber). Når man lærer sit modersmål, eller eventuelt to hvis man vokser op i en tosproget familie, udvikler man sin tilhørende personlige sprogkultur, alle sine personlige konnotationer osv. Når man så senere i livet lærer et andet sprog som fremmedsprog, vil man i den første lange tid trække på sit modersmåls sprogkultur i tilegnelsen af det nye sprog. Man danner så at sige en blanding bestående af det ene sprogs (målsprogets) udtryksside og det andet sprogs (modersmålets) indholdsside. Sådan kan man fx tale 'engelsk' med et stort tilskud af dansk sprogkultur - ordene lyder engelske, men har danske betydninger.

Når man bevæger sig rundt i verden som turist eller migrant af en eller anden slags, bærer man sine sproglige og sprogkulturelle kompetencer og ressourcer med sig, og hvis man slår sig ned i længere tid, sker der sandsynligvis en mere eller mindre dybtgående transformation af sprogkulturen, afhængigt af de nye sproglige behov og af det eventuelle møde med et sprog på det nye sted. Hos den enkelte er idiolekten og dens sprogkultur således en enhed, der hele tiden udvikler sig, og som godt kan undergå store ændringer, hvis den sociale, kulturelle og sproglige kontekst bliver en anden.

\section{Sprogkulturen i den sproglige praksis}

Jeg har talt om eksempelsætningen som et møde mellem elementer fra tre sprog: engelsk, fransk og tysk. Det er sprogmødet i selve teksten. Men i den kontekst, som teksten fungerede i da jeg fandt den, indgik den i en kommunikativ begivenhed, et stykke flersproget praksis indeholdende den opfordrende sproghandling: $\mathrm{K} ø \mathrm{~b} \mathrm{X}$. Afsenderen er en eller flere anonyme tekstproducenter og en anonym organisation, hvis rolle det er at markedsføre danske produkter. Der er således sandsynligvis foregået en længere intertekstuel proces, før den endelige tekst (på skiltet) havnede på det bornholmske postkontor. I den kommunikative begivenhed er der tale om et sprogmøde mellem afsenderne og de tænkte modtagere, de 
udenlandske turister i Danmark (ikke specielt på Bornholm, for det hedder jo ikke Buy some petit souvenir aus Bornholm). Disse forstår og fortolker teksten ud fra hver deres forudsætninger, blandt andet den (flersprogede) sprogkultur, de hver især har udviklet.

Jeg vil her referere til Hannerz' teori om kulturelle strømme og kulturel kompleksitet (fx Hannerz 1992). En af hovedtankerne i hans teori er, at meaning (betydning, mening, ideer) strømmer fra menneske til menneske i stadige processer af eksternalisering og fortolkning, og at disse sprednings- eller fordelingsprocesser kan beskrives som foregående i sociale netværk af større eller mindre udstrækning. De strømme og netværk, der især interesserer ham, er de store transnationale, og han mener, at man kan anskue enhver lokalitet som en lokal organisering af en kulturel diversitet eller kompleksitet, der opstår ved at forskellige kulturelle strømme mødes. I enhver lokalitet er der potentielt transnationale forbindelser til mange forskellige steder i verden.

Denne forholdsvis generelle teori kan tjene som ramme for det jeg her har sagt om sprogmøder. Hannerz har ikke beskæftiget sig specifikt med sproget som en del af kulturen, men jeg mener, at metaforen om kulturelle strømme kan bruges på sprogene: Sproglig praksis i et bestemt sprog, fx dansk, spreder sig fra menneske til menneske i en stadig produktions- og interpretationsproces, der foregår i de sociale netværk, man færdes i og opbygger. Da mennesker samtidig også bevæger sig rundt og måske migrerer til en anden del af verden, 'strømmer' deres sprog og sprogkultur med, og således spredes sprogene, fx dansk, rundt omkring i større eller mindre netværk over hele verden. De globale medier bidrager til at denne transnationale sprogspredning kan udnyttes intensivt gennem elektronisk formidlet kommunikation på fx dansk, uanset hvor i verden folk befinder sig.

Hannerz' teori er forholdsvis svag med hensyn til den sociale og politiske dimension og magtdimensionen. Jeg vil mene, at denne dimension må styrkes, blandt andet når man fokuserer på forholdet mellem sprogene. Når flere forskellige sprog bruges inden for den samme samfundsmæssige sammenhæng (en transnational virksomhed, en stat, et turistområde m.m.), er sprogene i en form for indbyrdes konkurrence eller kamp. Det kan blandt andet aflæses i de sproglige hierarkier, der skabes gennem forskellige gruppers valg eller fravalg af sprog $\mathrm{i}$ bestemte kontekster, fx i skolegården, i arbejdspladsens frokoststue, i mediernes forskellige kanaler (Risager 2005, 2006). Sprogmøder har altid en mere eller mindre tydelig magtdimension indbygget (jf. Bourdieus teori om den sproglige markedsplads og det legitime sprog, Bourdieu 1982). 


\section{Sprogmøder på mikroplanet analyseret som sprogkulturmøder}

I Buy some petit souvenir aus Dänemark finder tre forskellige sproglige strømme sammen, en engelsk som udgør en vidt forgrenet strøm over det meste af verden, især i de skoleuddannede lag af befolkningerne (bemærk dog at det stadig er sådan, at ca. $85 \%$ af jordens befolkning ikke forstår engelsk), en fransk og en tysk som begge også udgør forholdsvis forgrenede strømme, fordi de er officielle sprog (det gælder specielt fransk i de frankofone områder) eller obligatoriske/ valgfri fremmedsprog i mange landes skolesystemer (fransk og i mindre grad også tysk). Disse strømme har altså blandt andet gennem producenterne af denne tekst fundet vej til Danmark og bidrager til den sproglige mangfoldighed i Danmark. Strømmene fortsætter til dels ud af landet igen, når de udenlandske turister tager hjem, medbringende deres sprogkulturer. Måske bliver skiltet endda bortført af en begejstret hollandsk fransklærer og sat op i hans klasse i Holland.

Hvordan sprogmødet tog sig ud for de forskellige mennesker, der så skiltet, er naturligvis ikke til at vide, og det ville ikke være nogen let sag at gennemføre en retrospektiv receptionsundersøgelse af læsningen. Men man kan i hvert fald forestille sig, at ord som 'souvenir' og 'Dänemark' vakte forskellige forestillinger hos forskellige mennesker ud fra deres forskellige sprogkulturer og $\varnothing$ vrige viden og livserfaringer.

Hvad kunne være en souvenir fra Bornholm? Granitsmykker? Sildeopskrifter? Malerier af rundkirker? Det bornholmske flag? Turisterne kom med alle mulige forudsætninger, og med hensyn til sproglige kompetencer behøvede de ikke at være modersmålstalende i hverken engelsk, fransk eller tysk. En tyrkisk-tysk turist ville måske tænke på andre souvenir-muligheder end en dansk-svensker. I $\varnothing v$ rigt ville rækken af tænkelige souvenirs naturligvis se anderledes ud, hvis reklameskiltet optrådte i et andet turistområde, fx i Jylland. Lignende overvejelser kan man gøre sig om 'Dänemark': At benævne Danmark på tysk lagde op til andre forventninger end hvis det blev benævnt på fx engelsk. Hvilke diskurser om Dänemark cirkulerede i det tyske sprogsamfund? Hvilke forskelle var der på diskurserne om Dänemark i det tidligere Vest- og Østtyskland? Hvad ville en dansk-libanesisk turist forbinde med ordet Dänemark?

Alt dette blot for at understrege, at Buy some petit souvenir aus Dänemark kan analyseres som et sprogkulturmøde på mange planer, både på det tekstlige plan (mødet mellem elementer af tre sprog) og på det kommunikative plan (mødet mellem mennesker der er tresprogede). Noget lignende gælder også for de andre former for sprogmøder, jeg har nævnt. Alle sprogmøderne på mikroplanet kan ses som kommunikative møder mellem mennesker, der har udviklet forskellige, måske flersproglige, personlige sprogkulturer både med hensyn til den semantiskpragmatiske dimension, den poetiske dimension og den identitetsmæssige dimen- 
sion (med hensyn til sproglig identitet). Selvfølgelig må formålet med ens analyse være afgørende for, hvilke sider af sprogkulturmødet man vil lægge vægt på, eller om man overhovedet har brug for at belyse sprogmødet som et sprogkulturmøde.

Samtidig vil jeg understrege, at der ikke er noget prædetermineret link mellem sproglig identitet på den ene side og national eller etnisk identitet på den anden. Om der er sådanne links er et empirisk spørgsmål, der kræver, at man analyserer den kommunikative situation og ser på, om deltagerne rent faktisk trækker på diskurser om national eller etnisk identitet. Pointen med at vælge Buy some petit souvenir aus Dänemark som eksempel er blandt andet at vise, at vi her ikke har at gøre med nationalsprog i modersmålsforstand, men med et internationalt miljø der gør brug af forskellige sprog i rollen som tværnationale fremmedsprog.

\section{Sprogmøder på makroplanet analyseret som sprogkulturmøder}

Når det drejer sig om sprogmødet på makroplanet, såsom konkurrencen eller kampen mellem dansk og engelsk i Danmark, er det også muligt at se det som et sprogkulturmøde, idet man fremhæver den kulturelle dimension af samfundsmæssige forhold, der i høj grad også har sociale og politiske dimensioner.

I forbindelse med sprogmøder på makroplanet bruges der ofte diskurser, der abstraherer fra den sproglige praksis og taler om sprogene som enheder, 'dansk', 'engelsk' osv. Der er tale om et diskursivt greb, der reificerer sproglig praksis på forskellige måder. Man kan fx se sprog beskrevet som et system (arvtager fra strukturalismen) eller et redskab (en funktionel udlægning) eller en organisme der fødes, vokser og dør (en sproghistorisk fortælling) eller en person, der har en krop og sjæl, og som kan føle og handle (sprog kan æde hinanden eller bekrige hinanden, eller 'det danske sprog er en ung blond pige'). På makroplanet er det ikke så meget den semantisk-pragmatiske og poetiske dimension af sprogkulturen, der står i centrum, men den identitetsmaessige (selv om der naturligvis kan være interessante forskelle imellem to sprogs semantiske potentialer, fx vedrørende betegnelser for sociale, politiske og kulturelle grupperinger i henholdsvis engelsk og dansk). Ved den identitetsmæssige dimension af sprogkulturen er der fokus på identifikation af sprogene, og dermed de grupper der taler dem. Det er sprogbrugerne og de samfundsmæssige institutioner og organisationer, der er aktørerne her.

Fra et forskningsmæssigt synspunkt mener jeg det er vigtigt at se på de kulturelle, sociale og politiske aspekter af sprogmødet i sammenhæng og således integrere kulturanalytiske, sprogsociologiske og sprogpolitiske perspektiver (se fx De Swaan 2001, hvor sprogene ses i et verdenssystemperspektiv). Ved sprog- 

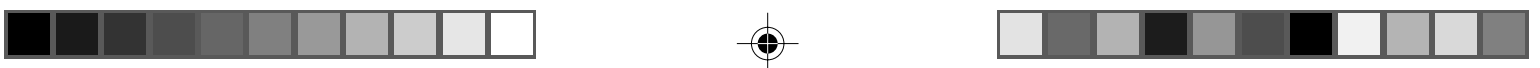

møder på makroplanet er der tale om relationer mellem sproggrupper/sprogsamfund, hvor magt spiller en væsentlig rolle. Hvilke sprog kan eller skal bruges i hvilke sammenhænge, hvad enten det er for at sikre kommunikationsbehov i samfundet og på tværs af sproggrupper, eller det er for at bidrage til symbolsk anerkendelse af bestemte gruppers sprog?

Det sproglige landskab i et flersproget samfund som det danske er præget af sociale hierarkier mellem sprogene. Nogle er lokale, andre mere generelle for samfundet som helhed. Et af hierarkierne kan beskrives som et tre-trins-hierarki, hvor det danske sprog befinder sig i midten og trænges fra to sider; 'oppefra' af engelsk og 'nedefra' af indvandrersprogene. Dansk kan ses som kæmpende en kamp mod engelsk på den ene side og mod indvandrersprogene på den anden. Forsvarerne for engelsk indbyder danskerne til at 'snobbe opad' og sætte pris på dansk-engelsk tosprogethed. Forsvarerne for indvandrersprogene anklager danskerne for at 'hakke nedad' og nedvurdere dansk-tyrkisk, dansk-arabisk osv. tosprogethed. Dansk som modersmål har høj værdi, hvorimod tyrkisk, arabisk osv. som modersmål har lav værdi. Hierarkiet er således en afbildning af en meget modsætningsfyldt omgang med centrale begreber som modersmål og tosprogethed (Lund \& Risager 2001).

Studiet af sprogmøder på makroplanet kan altså trække på sprogkulturbegrebet, især hvad angår den identitetsmæssige dimension, som omfatter kategorisering og identifikation af sprog, ideologier om sprog og sprogbrug, samt mere konkrete sprogpolitiske holdninger. Set i den større sammenhæng placerer Buy some petit souvenir aus Dänemark sig i den øvre ende af ovenstående hierarki, siden der her er et 'samarbejde' mellem engelsk og to store (europæiske) sprog, der begge har haft en stærk stilling som fremmedsprog i Danmark. Men i betragtning af de faldende kundskaber i andre fremmedsprog end engelsk i disse år i Europa kan man spørge hvem Buy some petit souvenir aus Dänemark henvender sig til, hvis den stadig bruges? Vil denne sprogblanding mellem engelsk, fransk og tysk være relevant fremover, eller er der tale om et fænomen, der hører det 20. århundredes turisme til?

\section{Litteratur}

Agar, Michae

1994 Language Shock. Understanding the Culture of Conversation. New York: William Morrow.

Auer, Peter (ed.)

$1998 \quad$ Code-Switching in Conversation. Language, Interaction and Identity. London and New York: Routledge. 
Bakhtin, Mikhail M.

1981 The Dialogic Imagination. Austin: University of Texas Press.

Bourdieu, Pierre

1982 Ce que parler veut dire. L'économie des échanges linguistiques. Paris: Fayard and-Culture. Clevedon: Multilingual Matters.

Byram, Michael, Carol Morgan et al.

1994 Teaching-and-Learning Language-and-Culture. Clevedon: Multilingual Matters.

De Swaan, Abram

2001 Words of the World. The Global Language System. Cambridge: Polity Press.

Friedrich, Paul

1989 Language, Ideology and Political Economy. American Anthropologist 91:295-312.

Hannerz, Ulf

1992 Cultural Complexity. Studies in the Social Organisation of Meaning. New York: University of Columbia Press.

Harris, Roxy

2006 New Ethnicities and Language Use. Hounsmill: Palgrave Macmillan.

Hymes, Dell

$1974 \quad$ Foundations in Sociolinguistics. An Ethnographic Approach. London: Tavistock Publications.

Jakobson, Roman

1960 Closing Statement: Linguistics and Poetics. I: Thomas Sebeok (ed.): Style in Language. Pp. 350-77. Cambridge, MA: MIT Press.

Jørgensen, Jens Normann (ed.)

2003 Bilingualism and Social Relations. Turkish Speakers in North Western Europe. Clevedon: Multilingual Matters.

Le Page, Robert \& Andrée Tabouret-Keller

1985 Acts of Identity. Creole-Based Approaches to Language and Ethnicity. Cambridge: Cambridge University Press.

Lund, Karen \& Karen Risager

2001 Dansk i midten. Sprogforum 19:4-8.

Pavlenko, Aneta \& Adrian Blackledge (eds.)

2004 Negotiation of Identities in Multilingual Contexts. Clevedon: Multilingual Matters.

Pennycook, Alastair

$1998 \quad$ English and the Discourses of Colonialism. London and New York: Routledge.

Quist, Pia

2005 Stilistiske praksisser i storbyens heterogene skole. En etnografisk og sociolingvistisk unders $\varnothing$ gelse af sproglig variation. Ph.d.-afhandling. Københavns Universitet: Nordisk Forskningsinstitut, Afdeling for dialektforskning.

Rampton, Ben

1995 Crossing. Language and Ethnicity Among Adolescents. London and New York: Longman. 
Risager, Karen

1993 Buy some petit souvenir aus Dänemark. Viden og bevidsthed om sprogmødet. I: Karen Risager, Anne Holmen \& Anne Trosborg (red.): Sproglig mangfoldighed og sproglig viden og bevidsthed. S. 30-42. ADLA, Roskilde Universitetscenter.

2003 Det nationale dilemma i sprog- og kulturpædagogikken. Et studie i forholdet mellem sprog og kultur. Doktordisputats. København: Akademisk Forlag.

2005 Sproglige eksklusionshierarkier - de hundrede sprogs betydning. Minoritetsstudiers Værksted 2. Institut for Tværkulturelle og Regionale Studier. Københavns Universitet.

2006 Language and Culture: Global Flows and Local Complexity. Clevedon: Multilingual Matters.

2007 Language and Culture Pedagogy. From a National to a Transnational Paradigm. Clevedon: Multilingual Matters.

Roberts, Celia et al.

2001 Language Learners as Ethnographers. Clevedon: Multilingual Matters. 
